\title{
Pengaruh Fasiltas Lingkungan Kerja dan Semangat Kerja Terhadap Produktivitas Kerja Karyawan Pada CV. Usaha Mandiri "Mimi" Palembang
}

\author{
Akila \\ Fakultas Ekonomi dan Bisnis Universitas PGRI Palembang, akilaali62@gmail.com
}

\begin{abstract}
ABSTRAK
Penelitian ini bertujuan untuk mengetahui (1) fasilitas lingkungan kerja pada CV. Usaha Mandiri "MIMI" Palembang. (2) Semangat kerja pada CV. Usaha Mandiri "MIMI" Palembang, (3) Pengaruh fasilitas lingkungan kerja dan semangat kerja terhadap produktivitas kerja karyawan pada CV. Usaha Mandiri "MIMI" Palembang. Metode penelitian variable independen dan variable dependen. Populasi dalam penelitian ini seluruh karyawan 36 orang, pengambilan sampel yang digunakan teknik sampling jenuh adalah sensus, semua karyawan dijadikan sampel, sumber data yang diperoleh data primer dan skunder. Teknik pengumpulan data dalam penulisan ini yaitu kuesioner atau angket (Questionairre). Teknik analisis data yang digunakan adalah analisis regresi linier berganda, analisis koefisien korelasi, analisis koefisien determinasi $R^{2}$ berganda dengan pengujian hipotesis uji t dan uji F di bantuan software SPSS 22 for windows. Dari hasil pengujian penelitian ini menunjukkan bahwa 1) Secara simultan terdapat pengaruh segnifikan fasilitas lingkungan kerja dan semangat kerja terhadap produktivitas kerja karyawan pada CV.Usaha Mandiri "MIMI" Palembang, 2) Secara parsial terdapat pengaruh segtifikan fasilitas lingkungan kerja terhadap produktivitas kerja karyawan pada CV. Usaha Mandiri "MIMI" Palembang, 3) Secara parsial juga ada pengaruh segnifikan semangat kerja terhadap produktivitas kerja karyawan pada CV. Usaha Mandiri "MIMI" Palembang.
\end{abstract}

Kata Kunci : Fasiltas, Semangat, dan Produktivitas.

\begin{abstract}
This study aims to determine (1) working environment facilities at CV. Independent Business "MIMI" Palembang. (2) The spirit of work on the CV. Independent Business "MIMI" Palembang, (3) The influence of work environment facilities and work spirit on employee productivity at CV. Independent Business "MIMI" Palembang. The research method is the independent variable and the dependent variable. The population in the study was 36 people, the sampling technique used was the census sampling technique, all employees were sampled, the data sources obtained were primary and secondary data. The data collection technique in this writing was a questionnaire or questionnaire (Questionnaire). The data analysis technique used is multiple linear regression analysis, correlation coefficient analysis, multiple $R^{2}$ determination coefficient analysis with hypothesis testing $t$ test and $F$ test with the help of SPSS 22 software for windows. From the results of this study indicate that 1) Simultaneously there is an effect of environmental facilities on employee work productivity at CV.Usaha Mandiri "MIMI" Palembang, 2) Partially there is a significant effect of work environment facilities on employee work productivity at CV. Independent Business "MIMI" Palembang, 3) Partially there is also a significant influence of work morale on employee work productivity on $\mathrm{CV}$. Independent Business "MIMI" Palembang.
\end{abstract}

Keywords: Facilities, Enthusiasm, and Productivity.

\section{A. PENDAHULUAN}

Dengan perkembangan dunia usaha dan kondisi perekonomian sekarang ini persainngan yang semakin pesat dan ketat. Perusahaan harus dapat memanfaatkan karena sebagian besar perusahaan mempunyai tujuan yang sama yaitu untuk mendapatkan laba secara oktimal serta didampingi tujuan yang lain. Untuk mencapai hasil yang secara optimal,maka perusahaan memberikan dorongan semangat dalam bekerja. Setiap perusahaan berusaha menjaga kelangsungan hidup perusahaannya. Majunya suatu perusahaan tergantung pada sumber daya manusia 
yang mengelolahnya,karena sumber daya manusia dalam menentukan keberhasilan perusahaan tidak dapat diabaikan, sumber daya manusia merupakan sumber keunggunlan daya saing yang mampu menghadapi berbagai tantangan. Tanpa adanya sumber daya manusia yang memadai maka suatu perusahaan akan kesulitan untuk mencapai tujuan. Untuk mencapai tujuan dari perusahaan,dibutuhkan produktivitas kerja yang baik dari para karyawannya.

Handoko dalam (Busro 2018 : 341) Produktifitas kerja adalah merupakan sikap mintal manusia dan usaha-usahanya untuk mencapai hasil yang lebih baik dengan menggunakan sumber daya seefektif mungkin yang akhirnya diukur dengan masukkan yang digunakan untuk mencapai hasil yang optimal. Dengan ini bahwa sumber daya manusia sangat dibutuhkan. Tanpah adanya sumber daya manusia yang memadai, maka suatu perusahaan akan kesulitan dalam menjalankan setiap kegiatan, terutaman yang berkaitan dengan produktivitas kerja karyawan.

Adapun yang mempengaruhi produktivitas kerja adalah fasilitas, karena dengan fasilitas yang lengkap akan memudahkan karyawan untuk melaksankan pekerjaan sehingga produktivitas akan tercapai. Fasilitas sebagai alat utama, karena sangat penting untuk diperhatikan oleh perusahaan, meskipun tidak melaksanakan proses produksi dalam suatu usaha. Fasiltas merupakan segala sesuatu yang digunakan atau dipakai oleh karyawan untuk melaksanakan tugas yang dapat mempermudah dan memperlancar pelaksanaan dan kegiatan segala sesuatu pekerjaan.Munawisyah dalam (Rifa'i,2019:5) Fasiltas kerja adalah segala sesuatu yang digunakan, dipakai,ditempati, dan dinikmati oleh pegawai baik dalam hubungan langsung dengan pekerjaan maupun untuk kelancaran pekerjaan. Dengan ini bahwa fasilitas merupakan sarana untuk kelancaran dan memudahkan pelaksanaan fungsi dalam lingkungan kerja.

Selain fasilitas yang mempengaruhi produktivitas kerja terwujudnya kemajuan perusahaan adalah semangat kerja. Semangat kerja dapat diartikan sebagai suatu suasana kerja yang terdapat di dalam suatu perusahaan atau organisasi yang menunjukkan rasa kegairahan di dalam melaksanakan pekerjaan dan mendorong karyawan untuk bekerja secara lebih baik dan lebih produktif. Hasibuan (2014:94) semangat kerja dalah kemauan dan keinginan individu dalam melakukan pekerjaan dengan benar dan teratur sehingga akan memperoleh hasil yang maksimum. Semangat kerja timbul dari dalam diri seseorang dalam melakukan setiap pekerjaan yang dilakukannya. Dengan ini bahwa apabila semangat kerja karyawan baik maka pekerjaan yang dilakukan akan cepat selesai dan sebalikknya apabila karyawan tidak semangat dalam bekerja maka pekerjaan yang dilakukan karyawan tersebut akan terbengkalai, sehingga akan mempengaruhi produktivitas kerja karyawan tersebut. Seseorang selalu bersemangat bekerja dan akan selalu mempunyai semangat yang tinggi dalam bekerja.

\section{B. KAJIAN TEORI}

\section{1). Fasilitas kerja}

Dalam suatu perusahaan untuk mencapai tujuan diperlukan sarana sangat pernting sebagai aktivitas pendukung yang digunakan dalam bekerja sehari-hari dalam perusahaan.Fasilitas yang digunakan bermacam-macam bentuk jenis maupun manfaatnya sesuai kebutuhan dan kemampuan perusahaan itu sendiri.

Munawirsyah dalam (Rifai, 2019:5). Fasilitas kerja adalah segala sesusatu yang digunakan,dipakai, ditempati, dan dinikmati oleh pegawai baik dalam hubungan langsung dengan pekerjaan maupun untuk kelancara pekerjaan. Moenir (2014:120) 
fasilitas kerja adalah jenis-jenis peralatan,perlengkpan kerja, dan fasilitas yang berfungsi sebagai alat utama untuk membantu dalam pelaksanaan pekerjaan. Fasilitas kerja terkait dengan lingkungan kerja, lingkungan kerja merupakan fasilitas kerja dengan adanya fasilitas kerja yang nyaman maka keryawan dapat melaksanakan kerja dengan baik.

Dengan ini bahwa fasilitas lingkungan kerja merupakan sarana untuk kelancaran dan memudahkan pelaksanaan aktivitas kerja. Fasilitas yang lain diberikan kepada karyawan juga berguna untuk kehidupan yang layak. Oleh karena itu fasilitas sangat menunjang dalam tercapainya produktivitas kerja karyawan. Diperusahaan CV.Usaha Mandiri "MIMI" Palembang fasilitas sangat diperlukan demi kelancaran usahan tersebut. Fasilitas kerja perushaan berbeda-bedan dalam bentuk dan jenisnya tergantung besar kecilnya persuahaan.

\section{2) Faktor-faktor yang Mempengaruhi Fasilitas Kerja}

Husnan dan Ranupandjojo dalam (Dahlius dan Ibrahim,2016:4) Adapun faktorfaktor yang mempengaruhi fasilitas kerja sebagai berikut:

$\checkmark \quad$ Penyediaan kafetaria, untuk mempermudah karyawan yang ingin makan dan tidak sempat pulang.

$\checkmark \quad$ Perumahan,perusahaan dapat menyediakan fasilitas rumah meskin bukan semuah karyawan yang berupa asrama atau memeberi tunjangan untuk karyawan.

$\checkmark \quad$ Fasiltas pembelian, perusahaan menyediakan toko dimana parah karyawan dapat memebeli dengan harga yang rendah.

$\checkmark \quad$ Fasilitas kesehatan, menyediakan fasilitas kesehatan dangan program pemeliharaan kesehatan para karyawan di dalam menjalankan pekerjaanya.

$\checkmark \quad$ Penasehat keuangan,pemberian fasilitas agar para karyawan tidak mengalami kesulitan dalam mengatur keuangan.

$\checkmark \quad$ Fasilitas pendidikan,fasilitas ini biasanya berbentuk perpusatakaan yang bisa dimanfaatkan oleh para karyawan yang ingin menambah pengetahuan merka dengan cara membaca.

\section{3) Indikator-indikator Fasilitas Kerja}

Moenir (2015:120) Indikator-indikator fasiltas kerja sebagai berikut;

$>$ Gedung, dengan segala sarana yang diperlukan, termasuk jalan,selokan,air bersih, pembuangan air kotor dan halam parkir.

$>$ Rung kerja dan ruangan lainnya, tempat sholat atau mushola.

$>$ Alat-alat yang berfungsi untuk penyegar ruangan seperti kipas angin, AC.

$>$ Akses Internet merupakan kemampuan individu dan organisasi untuk bterhubung ke internet menggunakan komputer dan perangkat lainya.

\section{4) Semangat Kerja}

Semangat kerja dapat diartikan sebagai kekuatan-kekuatan psikologi yang bersifat positif dan beranikaragam yang mampu meningkat untuk kerja karyawan yang pada akhirnya mampu meningkat semangat kerja bagi karyawan. Dapat diartikan juga Semangat kerja sebagai suatu suasana kerja yang terdapat di dalam suatu organisasi yang menjukkan rasa gairah di dalam melaksanakan pekerjaan dan mendorong karyawan untuk bekerja secara lebih baik dan lebih produktif. Busro (2018:325). Semangat kerja juga merupakan suatu sikap positif yang memandang pekerjaan sebagai hal yang penting dengan ditandai sikap yang melakukan pekerjaan dengan sungguh-sungguh atau optimal. Dengan ini bahwa semangat kerja baik, maka pekerjaan yang dilakukan akan cepat selesai dan sebaliknya 
apabila semangat kerja tidak baik maka pekerjaan yang dilakukan akan terbengkalai, sehingga mempengaruhi produktifikas kerja karyawan.

\section{5) Faktor-faktor Yang Mempengaruhi Semangat Kerja}

Anarogo dalam (Busro 2018:327) Adapun faktor-faktor yang mempengaruhi semangat kerja sebagai berikut :

a. Job security,semangat yang dipegang karyawan tersebut merupakan pekerjaan yang aman dan relatif tetap, jadi bukan pekerjaan atau jabatan yang mudah digeser dan lain-lain.

b. Opportunities for advancement (kesempatan untuk mendapatkan kemajuan), Perusahaan yang memberikan kesempatan bagi karyawan untuk mengembangkan diri atau kariernya dapat berkembang, akan dapat mendorong karyawan lebih bersemangat dalam bekerja dalam dan menyelesaikan tugasnya.

c. Kondisi kerja yang menyenangkan.

Suasana lingkungan kerja yang harmonis, tidak tegang,merupakan syarat bagi timbulnya semangat kerja.

d. Kepemimpinan yang baik,menimbulkan rasa takut pada karyawan, akan menimbulkan rasa hormat karyawan, dan mampu meningkatkan karja karyawan.

e. Kompensasi,gaji dan imbalan,faktor ini sangat mempengaruhi semangat kerja karyawan.

\section{6) Indikator-indikator Semangat Kerja} berikut:

Nitisemito (2010:427) adapun indikator-indikator semangat kerja sebagai

a. Naikknya Produktivitas Karyawa

Karyawan yang semangat kerjanya tinggi cendrung melaksanakan tugas-tugas sesuai waktu,tidak menunda pekerjaan dengan sengaja, serta mempercepat pekerjaan dan sebagainya. Naiknya produtivitas karyawan dapat diukur dengan menggunakan tiga indikator sebagai berikut: (1) Profesionalisme dalam menyelesaikan pekerjaan, (2) Tidak menunda pekerjaan, (3) Mempercepat pekerjaan.

b. Tingkat Absensi Rendah

Tingkat absen rendah merupakan salah satu indikasi meningkatkan semangat kerja, karena presentase absen seluruh karyawan rendah.Absen yang rendah akan diikur dengan menggunakan empat indikator sebagai berikut: (1) Cuti, (2) Keterlambatan, (3) Alfa, (4) Sakit.

\section{c. Labour Turn Over}

Tingkat karyawan keluar masuk, karyawan yang menurun merupakan salah satu indikasi meningkatnya semangat kerja. Hal ini dapat disebabkan oleh kesenangan mereka bekerja pada perusahaan tersebut. Tingkat keluar masuk karyawan yang tinggi dapat mengganggu jalannya perusahaan. Labour Turn Over diukur dengan menggunakan 2 indikator sebagai berikut : (1) setia terhadap perusahaan, (2) senang bekerja di dalam perusahaan.

d.Berkurangnya Kegelisahan, Semangat kerja karyawan akan meningkat apabilah mereka gelisah.Kegelisahan dapat dilihat melalui keluhan, ketidak tenangan bekerja, dan hal-hal yang lain. Berkurang kegelisahan diukur dengan menggunakan empat indikator sebagai berikut : (1) kepuasan kerja, (2) 
ketenangan dalam bekerja, (3) keamanan dan kenyamanan dalam bekerja, (4) Hubungan kerja yang harmonis.

\section{7). Produktivitas Kerja}

Siagian (2018:75) produktivitas kerja adalah kemampuan memperoleh manfaat yang sebesar-besarnya dari sarana dan perasarana yang tersedia dengan menhasilkan output yang optimal bahkan kalau mungkin yang maksimal.

Sedangkan Komarudin (2019:121), produktivitas kerja adalah pada hakekatnya meliputi sikap yang senantiasa mempunyai pandangan bahwa metode kerja hari ini harus lebih baik dari metode kerja hari kemaren dan dengan hasil yang didapat raih esok harus lebih bermutuh dari hasil yang diraih hari ini. Dengan ini bahwa produktivitas merupakan perbandingan antara sumbe daya (input) dengan jumlah barang atau jasa (output) yang dihasilkan.Bahwa produktivitas kerja merupakan tingkat pencapaian atau hasil kerja seseorang dari sasaran yang harus dicapai yang harus dilaksanakan sesuai dengan semangat masing-masing, yang selalu mencari perbaikan terhadap apa yang telah ada. Produktivitas manusia mepunyai peranan besar untuk menentukan suksesnya perusahaan sering disebut dengan sikap mental yang selalu memiliki suatu keyakinan seseorang dapat melakukan pekerjaan lebih baik hari ini dari pada hari kemaren dan hari esok lebih baik hari ini.

8). Faktor-Faktor yang Mempengaruhi Produktivitas Kerja.

Burso (2018:348) Adapun faktor-faktor yang mempengaruhi produktivitas kerja ada empat belas sebagai berikut;

$\checkmark$ Motivasi kerja karyawan

$\checkmark$ Pendidikan dan pelatihan

$\checkmark$ Kedisiplinan, kejujuran,ketekunan.

$\checkmark$ Gizi dan Kesehatan karyawan

$\checkmark$ Keterampilan dan kompetensi.

$\checkmark$ Sikap dan etikakerja (karakter).

$\checkmark$ Kemampuan kerjasama dalam satu tim kerja.

$\checkmark$ Gaji,penghasilan,tunjangan kinerja.

$\checkmark$ Lingkunga fisik dan sosial.

$\checkmark$ Kecanggihan teknologi yang digunakan.

$\checkmark$ Dukungan faktor produksi.

$\checkmark$ Jaminan social yangditerima.

$\checkmark$ Manajemen dan kemimpinan.

$\checkmark$ Kesempatan berprestasi.

9). Indikator-indikator Produktivitas Kerja. berikut:

Sutrisno (2017:104) Indikator-indikator produktivitas kerja di ukur sebagai

a. Kemampuan,seorang karyawan dalam melaksanakan tugas sangat bergantung pada ketermapilan yang dimiliki serta profesional dalam bekerja.

b. Berusaha meningkatkan hasil yang dicapai, merupakan salah satu yang dapat dirasakan baik oleh yang mengerjakan maupun yang menikmati hasil pekerjaan tersebut.

c. Semangat kerja,merupakan usaha untuk lebih baik dari hari kemarin.

d. Pengembangan diri,dapat dilakukan dengan melihat tantangan dan harapan dengan apa yang dihadapi. 
e. Mutu,merupakan hasil pekerjaan yang dapat menunjukkan kualitas kerja seorang pegawai.

f. Efisiensi,merupakan perbandingan antara hasil yang dicapai dengan keseluruhan sumber daya yang digunakan.

\section{METODE PENELITIAN}

\section{1) Variabel Penelitian}

Variabel penelitian merupakan suatu atribut atau sifat atau nilai dari orang, objek, kegiatan yang mempunyai variasi tertentu yang ditetapkan oleh peneliti dan kemudian ditarik kesimpulannya. Sugiyono (2018:96). Variabel dalam penelitian ini terdiri dari dua variabel yaitu variabel bebas dan variabel terikat. Variabel bebas (variabel independen) merupakan variabel yang mempengaruhi atau yang menjadi sebab perubahannya atau timbulnya variabel dependen (terikat). Variabel bebas (X1) dalam penelitian ini terdiri dari fasilitas dilingkungan kerja (X1) dan semangat kerja (X2). Variabel Terikat( Variabel Dependen) merupakan variabel yang dipengaruhi atau yang menjadi akibat, karena adanya variabel bebas. Variabelterikat (Y) dalam penelitian ini adalah produktivitas $(Y)$.

\section{2) Defenisi Operasional}

a) Fasilitas lingkungan kerja

Fasilitas lingkunag kerja adalah segala sesuatu yang digunakan atau dipakai oleh karyawan untuk melaksanakan tugas atau pekerjaan yang dapat mempermudah dan memperlancar pelaksanaan dan segala kegiatan dalam suatu pekerjaan. (Moenir, 2015:120). Dengan ini indikator yang ditetapkan dalam penelitian adalah sebagai berikut; gedung, runga kerja, AC, Akses internet.

b) Semangat Kerja

Semangat kerja merupakan suatu sikap positif yang memandang pekerjaan sebagai hal yang penting ditandai dengan sikap melakukan pekerjaan dengan sunggu-sunggu atau optimal. Nitisemito (2010:427) Dengan Indikator yang digunakan dalam penelitian ini sebagai berikut; naiknya produktivitas karyawan, tingkat absen rendah, tingkat karyawan keluar masuk, berkurangnya kegelisahan.

c) Produktivitas Kerja

Produktivitas kerja merupakan implementasi dari rencana yang telah disusun tersebut. Implementasi peroduktivas kerja dilakukan oleh sumber daya manusia yang memiliki, ukuran yang menunjukan pertimbangan antara input dan output yang dikeluarakan perusahaan serta peran tenaga kerja yanh dimiliki persatuan waktu. Sutrisno, (2017:129) Dengan Indikator dalam penelitian ini sebagai berikut, kemampuan, berusaha meningkatkan hasil yang dicapai, semangat kerja, pengembangan diri, mutu, efesiensi.

\section{3) Populasi dan Sampel}

Sujarweni (2019:80) populasi adalah keseluruhan jumlah yang terdiri atas objek atau subjek yang mempunyai karakteristik dan kualitas tertentu yang ditetapkan oleh peneliti dan dipelajari kemudian ditarik kesimpulannya. Populasi dari penelitian ini adalah karyawan CV. Usaha Mandiri "MIMI" Palembang berjumlah 36 orang. Pengambilan sampel dari penelitian ini teknik sampling jenuh. Sampling jenuh adalah teknik penentuan sampel bila semua anggota digunakan sebagai sampel. Istilah lain sampel jenuh adalah sensus, dimana dimana semua anggota populasi dijadikan 
sampel. Untuk sumber data yang di peroleh data primer adalah data yang diperoleh dari responden melalui kusioner, kelompok fokus, dan planel, atau juga data hasil wawancara peneliti dengan nara sumber. Data yang diperoleh dari data primer ini harus diolah lagi. Sumber data yang langsung memberikan data kepada pengumpul data.Untuk data sekunder merupakan data yang didapat dari cacatan, buku, dan artikel, buku-buku teori, majalah dan sebagainya. Data yang diperoleh dari data sekunder ini tidak perlu diolah lagi. Sumber yang tidak langsung memberikan data pada pengumpul data.

\section{4) Teknik Pengumpulan Data}

Teknik pengumpulan data dalam penelitian ini yaitu kuesioner atau Angket (Questionairre). Sujarweni (2019:94) kuesioner merupakan teknik pengumpulan data yang dilakukan dengan cara memberi seperangkat pentanyaan atau pernyataan tertulis kepada para responden untuk dijawab.

\section{5) Teknik Uji Coba Instrumen}

Dalam penelitian ini penulis menggunakan teknik uji instrumen yang meliputi uji validitas dan reliabilitas. Sujarweni (2019:165) menjelaskan bahwa uji validitas adalah alat analisis yang digunakan untuk mengukur valid atau tidak suatu pertanyaan / kusioner. Kusioner / pertanyaan dikatakansah atau valid jika pertanyaan pada kusioner tersebut mampu mengungkapkan sesuatu yang akan diukur oleh kusioner itu, uji signifikan dilakukan dengan membandingkan nilai $r$ hitung dengan nilai $r$ table. Sedangkan uji reliabilitas dilakukan korelasi terhadap item pertanyaan yang dinyatakan valid. Uji ini digunakan untuk mengukur suatu kusioner yang merupakan indikator dari variabel. Suatu kusioner dikatakan reliabel atau handal jika jawaban seseorang terhadap perntanyaan adalah konsisten atau stabil dari waktu kewaktu. Untuk pengujian reliabilitas peneliti menggunakan alat ukur skala rentangan (seperti skalalikert 1-5) yaitu croanbach's alpha $>0,60$. Diuji menggunakan bantuan komputer dengan program SPSS Versi 22.

\section{6) Uji Asumsi Klasik}

\section{a) Uji Normalitas}

Sujarweni (2019:225) uji normalitas bertujuan untuk menguji apakah dalam model regresi variabel terikat $(X)$ dan variabel bebas $(Y)$ keduanya mempunyai distribusi normal atau tidak. Uji normalitas data dapat dilakukan dengan menggunakan uji Kolmogorow Smirnov satu arah. Pengambilan kesimpulan untuk menentukan apakah suatu data mengikuti distribusi normal atau tidak adalah dengan menilai signifikan. Jika signifikan > 0,05 maka variabel berdistribusi normal dan sebaliknya jika signifikan < 0,05 maka variabel tidak berdistribusi normal.

b) Uji Multikolinearitas

Sujarweni (2019:227) menjelaskan bahwa uji multikolinieritas berarti ada hubungan linier yang sempurna atau pasti diantara beberapa semua variabel yang independen dari model yang ada. Akibat adanya multikolinieritas ini koefisien regresi tidak tertentu dan kesalahan standard tidak terhingga. Hal ini akan menimbulkan bias dalam spesifikasi. Uji multikolieritas bertujuan untuk menguji apakah pada model regresi ditemukan korelasidi antara variabel bebas.

Metode untuk menguji dan yang multi kolieritas ini dapat dilihat dari Tolerance Value Variance Inflantion Factor (VIF). Jika VIF $>10$ ataujika tolerance value $<0,1$ 
maka terjadi multikolinearitas. Jika VIF $<10$ atau jika tolerance value $>0,1$ maka tidak terjadi multikolinearitas.

c) Uji Heteroskedastisitas

Ghozali (2013), uji heteroskedastisitas bertujuan menguji apakah dalam model regresiter jadi ketidak samaan varians dari residual satu pengamatan kepengamatan yang lain. Jika varians tetap maka disebut homoskedastisitas dan jika berbeda maka terjadi problem heteroskedastisitas. Model regresi yang baik yaitu homoskesdatisita satau tidak terjadi heteroskedastisitas.

Untuk mendeteksi adanya heteroskedastisitas dilakukan dengan menggunakan teknik uji koefisienkorelasi spearman's rho yaitu mengorelasikan variabel independen dengan residualnya. Kriteria pengujian dengan menggunakan tingkat signifikan 0,05 dengan uji 2 sisi. Jika korelasi antara variabel indenpenden dengan residualnya memberikan signifikan lebih dari 0,05, maka dapat dikatakan bahwa tidak terjadi problem heteroskedasitas.

\section{7) Teknik Analisis Data}

a) Analisis Regresi Linier Berganda

Menurut Priyatno (2014:148) mengemukakan bahwa analisis regresi ini bertujuan untuk mengetahui pengaruh atau hubungan secara linier antara dua atau lebih variabel bebas dengan variabel terikat. Analisis regresi ini dinyatakan dengan persamaanse bagaiberikut:

$Y^{\prime}=a+b 1 X 1+b 2 X 2+e$

b) Koefisien Korelasi

Siregar (2013:337) menjelaskan bahwa koefisien korelasi adalah bilangan yang menyatakan kekuatan hubungan antara dua variabel atau lebih, atau dapat menentukan arah hubungan dari kedua variabel. Nilai korelasi $(r)=(-10 \leq 1)$. Untuk kekuatan hubungan, nilai koefisien korelasi berada di antara -1 sampai 1 , sedangkan untuk arah dinyatakan dalam bentuk positif $(+)$ dan negatif $(-)$. Apabila $r=-1$ korelasi negative sempurna, artinya terjadi hubungan bertolak belakang antara variabel $X$ dan variabel $Y$. Jika variabel $X$ naik, makavariabel $Y$ turun. Apabila $r=1$ korelasi positifs empurna, artinya terjadi hubungan searah variabel $X$ dan variabel $Y$. Jika variabel $X$ naik, maka variabel $\mathrm{Y}$ naik.

c) Koefisien Determinasi $\left(\mathrm{R}^{2}\right)$

Ghozali dalam (Sujarweni 2019:228) menjelaskan bahwa koefisien determinasi yang dinotasikan dengan $\mathrm{R}^{2}$ merupakan suatu ukuran yang penting dalam regresi. Determinasi $\left(R^{2}\right)$ mencerminkan kemampuan variabel dependen. Tujuan analisis ini adalah untuk menghitung besarnya pengaruh variabel independen terhadap variabel dependen. Nilai $R^{2}$ menunjukkan seberapa besar proporsi dari total variasi variabel tidak bebas yang dapat dijelaskan oleh variabe Ipenjelasannya. Semakin tinggi nilai $\mathrm{R}^{2}$ maka semakin besar proporsi dari total varias ivariabel dependen yang dapat dijelaskan oleh variabel independent. Nilai koefisien determinasi adalah antara nol (0) dan (1). Nilai $R^{2}$ yang kecil berarti kemampuan-kemampuan variabel independent (bebas) dalam menjelaskan variasi variabel dependent sangat terbatas.

\section{8) Pengujian Hipotesis}

a) Uji t (SecaraParsial)

Sujarweni (2019:229) mengungkapkan uji t menunjukan seberapa jauh pengaruh satu variabel independen atau variabel penjelas secara individu dalam 
menerangkan variabel dependen. Apabilah nilai probabilitas signifikansinya lebih kecil dari 0,05 (5\%) maka suatu variabel independen berpengaruh signifikan terhadap variabel dependen. Hipotesis diterima jika taraf signifikan (a) $<0,05$ dan hipotesis ditolak jika tarif signifikan (a) $>0,05$.Kriterianya Jika $\mathrm{t}<0,05$, maka Ho ditolak dan Ha diterima dan Jika $t>0,05$, maka Ho diterima dan Ha ditolak.

b) Uji F (Secara Simultan)

Sujarweni (2019:228) menjelaskan bahwa signifikan model regresi secara simultan diuji dengan melihat nilai signifikan (sig) dimana jika nilai sig dibawah 0,05 maka variabel bebas (independent) berpengaruh terhadap variable terikat (dependen). Uji F-statistik digunakan untuk membuktikan ada pengaruh antara variabel bebas (independent) terhadap variabel terikat (dependen) secara simultan. Adapun kriteriajika $f<0,05$, maka Ho di tolak dan Ha diterima dan jika $f>0,05$, maka Ho diterima dan Haditolak.

\section{HASIL PENELITIAN}

1). Pengujian Instrumen

a) Uji Validitas

Untuk menguji validitas kuesioner dalam penelitian ini digunakan rumus korelasi product moment yang dilakukan terhadap 36 responden. Uji valitas ini untuk menjamin bahwa intrumen telah sesuai dengan penelitian variabel. Penelitian ini membandingkan nilai $r$ hitung dengan nilai $r$ tabel. Butir pertanyaan dinyatakan valid apabila $r$ hitung lebih besar dari $r$ tabel. Analisis validitas kuesioner meliputi variabel fasilitas lingkungan kerja (X1), semangat kerja (X2), dan produktifitas kerja karyawan $(\mathrm{Y})$.

Tabel Hasil Validitas (X1)

\begin{tabular}{|c|c|c|}
\hline r hitung & $\boldsymbol{r}$ tabel & Validitas \\
\hline 0,587 & 0,329 & Valid \\
\hline 0,503 & 0,329 & Valid \\
\hline 0,658 & 0,329 & Valid \\
\hline 0,470 & 0,329 & Valid \\
\hline 0,726 & 0,329 & Valid \\
\hline 0,700 & 0,329 & Valid \\
\hline 0,705 & 0,329 & Valid \\
\hline 0,620 & 0,329 & Valid \\
\hline
\end{tabular}

Sumber: Data primer yang diolah, 2021

Tabel Hasil Uji Validitas (X2)

\begin{tabular}{|c|c|c|}
\hline $\boldsymbol{r}$ hitung & $\boldsymbol{r}$ tabel & Validitas \\
\hline 0,522 & 0,329 & Valid \\
\hline 0,418 & 0,329 & Valid \\
\hline 0,689 & 0,329 & Valid \\
\hline 0,649 & 0,329 & Valid \\
\hline 0,479 & 0,329 & Valid \\
\hline 0,789 & 0,329 & Valid \\
\hline 0,625 & 0,329 & Valid \\
\hline 0,554 & 0,329 & Valid \\
\hline
\end{tabular}

Sumber: Data primer yang diolah, 2021 
Tabel Hasil Uji Validitas ( $\mathrm{Y}$ )

\begin{tabular}{|c|c|c|}
\hline r hitung & r tabel & Validitas \\
\hline 0,525 & 0,329 & Valid \\
\hline 0,558 & 0,329 & Valid \\
\hline 0,663 & 0,329 & Valid \\
\hline 0,604 & 0,329 & Valid \\
\hline 0,728 & 0,329 & Valid \\
\hline 0,749 & 0,329 & Valid \\
\hline 0,747 & 0,329 & Valid \\
\hline 0,462 & 0,329 & Valid \\
\hline
\end{tabular}

Sumber: Data primer yang diolah, 2021

Berdasarkan dari tabel hasil perhitungan untuk ketiga variabel dari 8 butir pertanyaan dipereroleh nilai $r$ hitung untuk variabel fasilitas lingkungan kerja (X1) semua valid karena $r$ hitung lebih besar dari $r$ tabel.Untuk variabel Semangat kerja (X2) semuanya valid karena $r$ hitung lebih besar dari $r$ tabel.Untuk variable Produktivitas kerja karyawan $(\mathrm{Y})$ semuanya valid karena $r$ hitung lebih besar dari $r$ tabel. Dengan demikian untuk penelitian selanjutnya ketiga variabel yaitu fasilitas lingkungan kerja (X1), semangat kerja (X2) dan produktivitas kerja karyawan ( $\mathrm{Y}$ ) menggunakan 8 butir pertanyaan, karena ketiga variable valid semua.

b) Uji Reliabilitas

Uji reliabilitas dilakukan untuk mengetahui tingkatan mana suatu tes secara koefisien mengukur berapapun hasil pengukuran itu.

Reliabilitas dinyatakan dengan angka-angka (biasanya sebagai suatu koefisien), koefisien yang tinggi menunjukkan reliabilitas yang tinggi. Hasil uji reliabilitas dalam pengujian dengan penelitian ini menggunakan koefisien Cronbach Alpha. Di mana instrumen dikatakan reliabel jika memiliki koefisien Cronbach Alpha $>0.60$. Hasil uji reliabilitas data dapat dilihat pada tabel berikut:

Tabel Hasil Uji Reliabilitas

\begin{tabular}{|c|l|c|c|}
\hline No. & \multicolumn{1}{|c|}{ Variabel } & Cronbach's Alpha & Keterangan \\
\hline 1 & Fasilitas Lingkungan Kerja & 0,772 & Reliabel \\
\hline 2 & Semangat Kerja & 0,735 & Reliabel \\
\hline 3 & Produktifitas Kerja & 0,788 & Reliabel \\
\hline
\end{tabular}

Sumber :Data primer yang diolah,2021

Hasil uji reliabilitas tersebut menunjukkan bahwa semua variable mempunyai koefisien cronbach alpha yang besar, yaitu diatas 0,60 sehingga dapat disimpulkan bahwa item-item pengukur tiga variable dari kuesioner adalah reliabel yang berarti bahwa kuesioner yang digunakan dalam penelitian ini merupakan kuesioner yang handal. Setelah dilakukan ujia validitas dan reabilitas, maka selanjutnya dilakukan analisis untuk menganalisis hopetesis dari penelitian ini.

\section{2) Uji Asumsi Klasik}

a) Uji Normalitas

Dalam penelitian ini menguji normalitas data dengan menggunakan One Sample Kolmogorov- Smirnov Test. 
Tabel Hasil Uji Normalitas

Taabel One-Sample Kolmogorov-Smirnov Test

\begin{tabular}{|l|l|r|}
\hline \multicolumn{2}{|l|}{} & Unstandardized Residual \\
\hline N & Mean & 36 \\
\cline { 2 - 4 } & Std. Deviation &, 0000000 \\
\hline Most Extreme Differences & Absolute & 3,77008493 \\
\cline { 2 - 3 } & Positive &, 132 \\
\cline { 2 - 3 } & Negative &, 084 \\
\hline Test Statistic &,- 132 \\
\hline Asymp. Sig. (2-tailed) & &, 132 \\
\hline
\end{tabular}

a. Test distribution is Normal.

b. Calculated from data.

c. Lilliefors Significance Correction.

Sumber: Data primer yang diolah, 2021

Berdasarkan hasil uji normalitas data menggunakan One Sample Kolmogorov Smirnov Test, Sebagaimana tersaji pada tabel diatas dapat disimpulkan bahwa variabel memiliki data normal, hal tersebut dikarenakan data tersebut memiliki Asymp. Sig > (a) 0,05.

b) Uji Multikolinearitas

Metode untuk menguji adanya multikolinearitas ini dapat dilihat dari Tolerance Value Variance Inflantion Factor (VIF). Jika VIF $>10$ atau jika tolerance value $<0,1$ maka terjadi multikolinearitas. Jika VIF $<10$ atau jika tolerance value $>0,1$ maka tidak terjadi multikolinearitas.

Tabel Hasil Uji Multikolinearitas

\begin{tabular}{|l|c|c|c|}
\hline \multicolumn{1}{|c|}{ Model } & \multicolumn{2}{|c|}{ Collinearity Statistics } & \multirow{2}{*}{ Keterangan } \\
\hline Constant & Tolerance & VIF & Tidak ada Multikolinearitas \\
\hline Fasilitas lingkungan kerja & 0,603 & 1,659 & Tidak \\
\hline Semangat kerja & 0,603 & 1,659 & Tidak ada Multikolinearitas \\
\hline
\end{tabular}

Sumber: Data primer yang diolah, 2021

Pada tabel tersebut menunjukkan semua angka VIF variabel model regresi lebih kecil dari 10 (VIF < 10), hal ini menunjukkan model regresi linier berganda tidak mempunyai persoalan multikolinearitas. Hasil perhitungan nilai tolerance juga menunjukkan tidak ada variabel independen yang nilainya kurang dari 0,1 (tolerance $>0,1$ ), yang berarti tidak ada korelasi antara variabel independen yang nilainya lebih dari $95 \%$, hal ini bearti tidak terjadi multikoliniritas.

c) Uji Heteroskedasitas

Untuk mendeteksi adanya adanya heteroskedastisitas dilakukan dengan menggunakan teknik uji koefisien korelasi spearman's rho yaitu mengorelasikan variabel independen dengan residualnya. Kriteria pengujian dengan menggunakan tingkat signifikan 0,05 dengan uji 2 sisi. Jika korelasi antara variabel indenpenden dengan residualnya memberikan signifikan lebih dari 0,05 , maka dapat dikatakan bahwa tidak terjadi problem heteroskedasitas. 


\section{Tabel Hasil Uji Heteroskedastisitas \\ Correlations}

\begin{tabular}{|c|c|c|c|c|c|}
\hline & & & $\begin{array}{c}\text { Fasilitas } \\
\text { Dilingkungan } \\
\text { Keria }\end{array}$ & $\begin{array}{c}\text { Semangat } \\
\text { Keria }\end{array}$ & $\begin{array}{c}\text { Unstandardized } \\
\text { Residual }\end{array}$ \\
\hline Spearman's rho & $\begin{array}{l}\text { Fasilitas } \\
\text { lingkungan }\end{array}$ & $\begin{array}{l}\text { Correlation } \\
\text { Coefficient }\end{array}$ & 1,000 &, $581^{* *}$ &,- 043 \\
\hline & kerja & Sig. (2-tailed) & & 000 & 805 \\
\hline & & $\mathrm{N}$ & 36 & 36 & 36 \\
\hline & $\begin{array}{l}\text { Semangat } \\
\text { Kerja }\end{array}$ & $\begin{array}{l}\text { Correlation } \\
\text { Coefficient }\end{array}$ &, $581^{* *}$ & 1,000 &, 049 \\
\hline & & Sig. (2-tailed) &, 000 & &, 775 \\
\hline & & $\bar{N}$ & 36 & 36 & 36 \\
\hline & $\begin{array}{l}\text { Unstandardizeo } \\
\text { Residual }\end{array}$ & $\begin{array}{l}\text { Correlation } \\
\text { Coefficient }\end{array}$ &,- 043 & ,049 & 1,000 \\
\hline & & Sig. (2-tailed) & 805 & 775 & \\
\hline & & $\mathrm{N}$ & 36 & 36 & 36 \\
\hline
\end{tabular}

**. Correlation is significant at the 0.01 level (2-tailed).

Sumber : Data primer yang diolah 2021.

Berdasarkan hasil uji heteroskedastisitas dengan menggunakan uji koefisien korelasi spearman's rho dapat dilihatbahwa korelasi antara variabel bebas (fasilitas dan semangat kerja) dengan unstandardized residual memiliki nilai signifikan lebih besar dari 0,05 . Karena signifikansi lebih besar dari pada 0,05 , residual memiliki nilai signifikan lebih besard ari 0,05, maka dapat disimpulkan bahwa tidak terjadi problem heteroskedasitas.

\section{3) Uji Regresi Linier Berganda}

Sugiyono (2018:275) uji regresi ganda digunakan oleh peneliti, bila peneliti bermaksud meramalkan bagaimana keadaan (naik turunnya) variabel dependen (kriterium), bila dua atau lebih variabel independen sebagai faktor prediktor dimanipulasi (dinaik turunkan nilainya). Jadi analisis regresi ganda akan dilakukan bila jumlah variable indepedennya miniman 2. Adapun proses pengelolaan data dilakunan dengan menggunakan program Statistical Package for the Social Science (SPSS) versi 22.0.

Adapun hasil regresi linier berganda tersebut disajikan pada berikut ini.

Tabel Hasil Uji Regresi Linier Berganda Coefficients $^{a}$

\begin{tabular}{|c|c|c|c|c|c|}
\hline \multirow[b]{2}{*}{ Model } & \multicolumn{2}{|c|}{$\begin{array}{l}\text { Unstandardized } \\
\text { Coefficients }\end{array}$} & \multirow{2}{*}{\begin{tabular}{|c|}
$\begin{array}{c}\text { Standardized } \\
\text { Coefficients }\end{array}$ \\
Beta \\
\end{tabular}} & \multirow[t]{2}{*}{$\mathrm{t}$} & \multirow[t]{2}{*}{ Sig. } \\
\hline & $B$ & Std. Error & & & \\
\hline \begin{tabular}{|ll}
1 & (Constant) \\
\end{tabular} & 6,062 & 4,688 & & 1,293 & 205 \\
\hline Fasilitas lingkungan kerja & ,387 & 155 & 398 & 2,488 & 018 \\
\hline Semangat kerja & 410 & 173 & 379 & 2,368 & 024 \\
\hline
\end{tabular}

Dependent Variable: ProduktivitasKerja

Sumber : Data primer yang diolah, 2021

Dari Hasil perhitungan table coeffcients ditas, di dapat hasil regresi linier berganda yaitu nilai kofisien regresi untuk fasilitas lingkungan kerja 0,387 dan nilai kofisien regresi untuk semangat kerja 0,410 dan nilai konstan sebesar 6,062. 
Berdasarkan table hasil uji regresi linier berganda dapat dibuat persamaan seperti berikut ini :

$$
Y^{\prime}=6,062+0,387 X 1+0,410 X 2
$$

\section{a). Uji Korelasi dan Koefisien Determinasi $\left(\mathbf{R}^{2}\right)$ Berganda.}

Uji korelasi ganda adalah suatu nilai yang memberikan kuatnya pengaruh atau hubungan dua variable atau lebih secara bersana-sama dengan variable lain.Sedangkan koefisien deterninasi digunakan untuk mengetahui seberapa besar pengaruh variable-variabel bebas memiliki pengaruh terhadap variable berikutnya. Pengujuan ini diuji dengan bantuan computer dengan menggunakan program SPSS versi 22, dengan output sebagai betikut:

\begin{tabular}{|c|c|c|c|c|}
\hline Model & $\mathrm{R}$ & $\begin{array}{c}\mathrm{R} \\
\text { Square }\end{array}$ & $\begin{array}{l}\text { Adjusted R } \\
\text { Square }\end{array}$ & $\begin{array}{l}\text { Std. Error of } \\
\text { the Estimate }\end{array}$ \\
\hline 1 &, $701^{a}$ & ,491 & ,461 & 3,883 \\
\hline
\end{tabular}

a. Predictors: (Constant), Semangat Kerja, Fasilitas

b. Dependent Variable: Produktivitas Kerja

Sumber : Data primer yang diolah, 2021

Berdasarkan tabel di atas diperoleh nilai $R$ sebesar $0,701^{\text {a }}$ ini menunjukkan bahwa nilai $R$ berada pada hubungan atau keeratan yang sangat kuat. Maka dapat disimpulkan bahwa variabel fasilitas dilingkungan kerja dan semangat kerja terdapat hubungan yang signifikan terhadap Produktivitas kerja karyawan.

Untuk koefisien determinasi (adjusted $\mathrm{R}^{2}$ ) dari hasil perhitungan dengan menggunakan program SPSS versi 22 dapat diketahui bahwa diperoleh nilai sebesar 0,461 sehingga dalam penelitian ini fasilitas dilingkungan kerja dan semangat kerja dapat mempengaruhi produktivitas kerja karyawan $46 \%$, sedangkan sisanya dipengaruhi oleh variabel-variabellainnya yang tidak diteliti dalam penelitian ini.

\section{b) Pengujian Hipotesis}

1) Hasil Uji $F$

Uji $F$ digunakan untuk mengetahui pengaruh variabel bebas (fasilitas lingkungan kerja dan semangat kerja) secara serenta katau simultan terhadap variabel terikat ( Produktivitas kerja karyawan). Uji $\mathrm{F}$ ditujukan untuk mengukur tingkat keberartian hubungan secara keseluruhan koefisien regresi dari variabel bebas terhadap variabel terikat dengan menentukan nilai uji $\mathrm{F}$ dengan tabel ANOVA (analysis of variance) dan tingkat signifikansi. Hasil pengujian tersebut adalah sebagai berikut: 


\section{Tabel Hasil Uji F (Simultan )}

ANOVA $^{\mathrm{a}}$

\begin{tabular}{|l|l|r|r|r|r|r|}
\hline \multicolumn{2}{|l|}{ Model } & $\begin{array}{c}\text { Sum of } \\
\text { Squares }\end{array}$ & Df & $\begin{array}{c}\text { Mean } \\
\text { Square }\end{array}$ & \multicolumn{1}{c|}{ F } & \multicolumn{1}{c|}{ Sig. } \\
\hline \multirow{2}{*}{1} & Regression & 480,832 & 2 & 240,416 & 15,948 &, $000^{\mathrm{b}}$ \\
\cline { 2 - 7 } & Residual & 497,474 & 33 & 15,075 & & \\
\cline { 2 - 7 } & Total & 978,306 & 35 & & & \\
\hline
\end{tabular}

a. Dependent Variable: Produktivitas Kerja

b. Predictors: (Constant), Semangat Kerja, Fasilitas Dilingkungan Kerja Sumber: Data primer yang diolah, 2021

Pengujian secara simultan menunjukkan bahwa nilai $F$ untuk model regresi adalah 15,948 dengan tingkat signifikansi $0,000<0,05$, maka tingkat signifikansi model regresi lebih kecil dari tarif nyata. Hasil ini menunjukkan bahwa variabel bebas yaitu fasilitas lingkangan kerja dan semangat kerja secara simultan mempunyai pengaruh yang signifikan terhadap produktifvas kerja karyawan.

2) Hasil Uji t

Uji parsial (uji-t) dilakukan untuk menguji Signifikansi Pengaruh variabelVariable bebas (fasilitas dilingkungan kerja dan semangat kerja) secara individual terhadap variable terikat (produktivitas kerja karyawan) pada CV. Usaha Mandiri "MIMI" Palembang. Uji-t dalam penelitian ini digunakan untuk melakukan pengujian hipotesis dengan tingkat signifikansi $(\alpha=0,05)$. Uji-t ditunjukkan pada tabel berikut:

Tabel Hasil Uji t (Parsial) Coefficients $^{a}$

\begin{tabular}{|c|c|c|c|c|c|}
\hline \multirow[b]{2}{*}{ Model } & \multicolumn{2}{|c|}{$\begin{array}{l}\text { Unstandardized } \\
\text { Coefficients }\end{array}$} & \multirow{2}{*}{\begin{tabular}{|c}
$\begin{array}{c}\text { Standardized } \\
\text { Coefficients }\end{array}$ \\
Beta
\end{tabular}} & \multirow[t]{2}{*}{$\mathrm{T}$} & \multirow[t]{2}{*}{ Sig. } \\
\hline & $\mathrm{B}$ & Std. Error & & & \\
\hline (Constant) & 6,062 & 4,688 & & 1,293 & ,20 \\
\hline Fasilitas lingkungan Kerja & ,387 & , 155 & ,398 & 2,488 &, 018 \\
\hline Semangat Kerja & , 410 & , 173 & ,379 & 2,368 & 024 \\
\hline
\end{tabular}

a. Dependent Variable: Produktivitas Kerja

Sumber: Data primer yang diolah, 2021

Berdasarkan hasil uji $t$ pada tabel diatas, maka diperoleh pengujian hipotesis dalam penelitian ini yaitu sebagai berikut:

$\checkmark \quad$ Uji Hipotesis Pertama

$\mathrm{H} 1 \quad$ : Ada pengaruh fasilitas dilingkungan kerja terhadap produktivitas kerja karyawan pada CV.Usaha Mandiri "MIMI" Palembang.

Berdasarkan tabel hasil Uji $t$ (Parsial) menunjukkan bahwa nilai $t$ sebesar 2,488 dengan signifikansi $0,018<0,05$. Hasil penelitian ini membuktikan kebenaran hipotesis 1 (satu) atau fasilitas dilingkungan kerja berpengaruh positif signifikan terhadap produktivitas kerja karyawan pada CV.Usaha Mandiri "MIMI" Palembang.

\section{$\checkmark \quad$ Uji Hipotesis Kedua}

$\mathrm{H} 2$ : Ada pengaruh semangat kerja terhadap produktivitas kerja karyawan pada CV.Usaha Mandiri "MIMI" Palembang.

Berdasarkan tabel hasil Uji $t$ (Parsial) menunjukkan bahwa nilai $t$ sebesar 2,368 dengan signifikansi $0,024<0,05$. Hasil penelitian ini membuktikan kebenaran 
hipotesis ke 2 (dua) atau semangat kerja berpengaruh positif signifikan terhadap produktivitas kerja karyawan pada CV. Usaha Mandiri "MIMI" Palembang.

\section{E. PEMBAHASAN}

\section{1) Pengaruh Fasilitas Lingkungan Kerja dan Semangat Kerja Terhadap Produktivitas Kerja Karyawan.}

Berdasarkan hasil uji $\mathrm{F}$ diperoleh nilai $\mathrm{F}$ untuk model regresi adalah 15,948 dengan tingkat signifikansi $0,000<0,05$ maka tingkat signifikansi model regresi lebih kecil dari taraf nyata. Hasil ini menunjukkan bahwa variabel bebas yaitu fasilitas lingkungan kerja dan semangat kerja secara simultan mempunyai pengaruh yang signifikan terhada pvariabel terikat yaitu produktivas kerja karyawan. Hipotesis juga menyatakan bahwa variabel fasilitas dilingkungan kerja dan semangat kerja berpengaruh secara signifikan terhadap variabel terikat produktivitas kerja karyawan.

Pengaruh secara serempak antara variabel bebas dan variabel terikat memberikan informasi yang kuat yaitu dibuktikan dengan koefisien determinasi (Adjusted $R^{2}$ ). Koefisien determinasi (Adjusted $R^{2}$ ) pada intinya menerangkan sebanyak mungkin variasi dalam variabel terikat dengan menggunakan variabel bebas dalam model. Suatu model dikatakan baik jika diukur dengan menggunakan nilai Adjusted $R^{2}$ yang setinggi mungkin.Nilai koefisien determinasi adalah antara nol (0) dan satu (1). Nilai $R^{2}$ yang kecil berarti kemampuan variabel-variabel independen (variabel bebas) dalam menjelaskan variasi-variabel dependen amat terbatas. Nilai yang mendekati satu berarti variabel-variabel independen memberikan hampir semua informasi yang dibutuhkan untuk memprediksi variasi variabel dependen.

Hasil koefisien determinasi diperoleh nilai adjusted $\mathrm{R}^{2}$ sebesar 0,701 atau $70 \%$. Hasil penelitian ini berarti bahwa $70 \%$ variasi variabel terikat yaitu produktivitas kerja karyawan dipengaruhi oleh variasi variabel bebas yaitu fasilitas dilingkungan kerja dan semangat kerja, sedangkan sisanya $30 \%$ dipengaruhi oleh faktor lainnya yang tidak dimasukkan kedalam model tersebut. Pembahasan berdasarkan perhitungan analisis dapat dinyatakan bahwa pengaruh fasilitas lingkungan kerja karyawan dan semangat kerja terhadap produktivitas kerja karyawan pada CV.Usaha Manidiri "MIMI" Palembang adalah signifikan.

Hasil uji asumsi klasik juga membuktikan bahwa model regresi memenuhi persyaratan karena terbukti data-data yang digunakan dalam analisis berdistribusi normal dan tidak terjadi gejala multikolinearitas dan heteroskedastisitas (hasil pada pembahasan uji asumsi klasik).

Berdasarkan analisis penelitian ini maka yang berpengaruh secaran nyata terhadap produktivitas kerja karyawan yaitu fasilitas lingkungan kerja (X1) berpengaruh positif signifikan, dan semangat kerja (X2) berpengaruh positif signifikan. Sejalan dengan penelitian terdahulu oleh Endang Syarif dan Imas Saadah (2017) bahwa secara simultan fasilitas dan semangat kerja berpengaruh terhadap produktivitas kerja karyawan.

\section{2) Pengaruh Fasilitas Lingkungan Kerja Terhadap Produktivitas Kerja Karyawan.}

Dari hasil regresi dapat dijelaskan bahwa variabel bebas fasilitas lingkungan kerja berpengaruh signifikan terhadap variabel terikat produktivitas kerja, variabel fasilitas lingkungan kerja menunjukkan hasil yang positif, artinya tinggi rendahnya fasiltas lingkungan kerja akan berbanding lurus atau diikuti dengan tinggi rendahnya 
produktivitas kerja karyawan pada CV. Usaha Mandiri"MIMI" Palembang. Hal ini didukung oleh hasil uji t dengan tingkat signifikansi 0,018 (signifikan< 0,05). Yang artinya fasilitas dilingkungan kerja Menyebabkan perubahan produktivitas kerja karyawan. Dengan demikian jika fasilitas lingkungan kerja tingkatkankan,maka akan berpengaruh atau dengan kata lain akan meningkatkan produktivas kerja karyawan. Hasil penelitian ini sesuai dengan teori Dahlius \& Ibrahim (2016:2), dalam suatu pencapaian tujuan suatu perusahaan, diperlukan alat atau sarana pendukung yang digunakan dalam aktivtas sehari-hari di perusahaan tersebut, fasilitas lingkungan kerja karyawan yang digunakan bermacam-macam bentuk, jenis maupun manfaatnya, disesuaikan dengan kebutuhan dan kemampuan perusahaan. Hasil penelitian ini juga diperkuat penelitian terdahulu yang dilakukan oleh Endang Syarif dan Imas Saadah (2017) yang menunjukkan bahwa fasilitas kerja dan berpengaruh secara signifikan terhadap produktivitas kerja.

\section{3) Pengaruh Semangat KerjaTerhadap Produktivitas Kerja Karyawan.}

Berdasarkan hasil penelitian semangat kerja berpengaruh terhadap froduktivitas kerja karyawan. Hal ini ditunjukkan dengan nilai $\beta=0,410$, hal ini dapat diartikan bahwa jika semangat kerja meningkat maka produktivitas kerja karyawan akan meningkat positif. Hasil pengujian hipotesis menunjukkan bahwa nilai $t$ hitung untuk semangat kerja adalah 2,368 dengan signifikansinya sebesar 0,001, sedangkan pada taraf signifikansise besar 0,05. Dengan demikian menunjukkan bahwa ada pengaruh semangat kerja terhadap produktivitas kerja karyawan pada CV. Usaha Mandiri "MIMI" Palembang. Kesimpulannya yaitu bahwa Ho ditolak dan Ha diterima, artinya ada pengaruh semangat kerja terhadap peoduktivitas kerja karyawan pada CV.Usaha Mandirir"MIMI" Palembang dapat diterima. Menunjukkan bahwa ada pengaruh positif semangat kerja terhadap produktivitas kerja karyawan. Hal ini berarti semakin baik semangat kerja, maka semakin tinggi produktivitas kerja karyawan, sebaliknya semakin kurang baik semangat kerja, maka semakin rendah produktivitas hasil kerja karyawan. Semangat kerja yang efektifakan meningkatkan hasil semangat kerja yang tinggi dari karyawan sehingga karyawan tersebut ingin mengembangkan dirinya agar menjadi karyawan yang lebih bermutu dan efisien. Dengan menciptakan semangat kerja yang efektif akan meningkatkan produktivitas kerja karyawan.

\section{F. KESIMPULAN DANSARAN}

\section{1) Kesimpulan}

Berdasarkan hasil kesimpulan peneliti, serta hasil analisis data dan pembahasan yang telah diuraikan sebelumnya, maka dapat diambil kesimpulan hasil penelitian sebagaiberikut:

a) Secara bersama-sama fasilitas dilingkungan kerja dan semangat kerja memiliki pengaruh yang signifikan terhadap produktifitas kerja karyawan pada CV. Usaha Mandiri "MIMI" Palembang.

b) Secara parsial fasilitas dilingkungan kerja memiliki pengaruh yang signifikan terhadap produktifitas kerja karyawan pada CV. Usaha Mandiri "MIMI" Palembang.

c) Secara parsial semangat kerja memiliki pengaruh yang signifikan terhadap produktivas kerja karyawan pada CV.Usaha Mandiri “MIMI” Palembang. 


\section{2) Saran}

Sehubungan dengan hasil penelitian yang telah disimpulkan di atas, peneliti merumuskan beberapa saran pada pihak CV.Usaha Mandiri "MIMI" Palembang sebagai berikut :

a) Bagi perusahaan perlu ditingkan lagi dengan memberikan fasilitas dilingkungan kerja yang lengkap dan kayawan diberikan dorongan semangat dalam melakukan setiap pekerjaan,sehingga karyawan dapat bekerja lebih baik dan memperoleh hasil yang maksimal.

b) Bagi perusahaan sebaiknya melakukan penilaian hal apa saja yang perlu dilakukan untuk meningkatkan produktivitas kerja, sehingga tujuan kedua belah pihak baik perusahaan maupun karyawan dapat tercapai dengan baik dari hasil yang diharapkan.

c) Bagi peneliti yang akan meneliti pada permasalahan yang sejenis, diharapkan memasukkan variabel lain di luar variabel yang sudah ada dalam penelitian ini.

\section{DAFTAR PUSTAKA}

Busro, M. (2018). Teori-teori Manajemen Sumber Daya Manusia . Jakarta : Prenada Media.

Endang Sayarif \& Imas Saadah. (2017). Pengaruh Fasilitas Kerja dan Komunikasi Terhadap Produktivitas Kerja Pegawai Pada Kantor Badan Pemberdayaan Masyarakat dan Keluarga Berencana Kabupaten Tasikmalaya : Jurnal Ekonomi Pedesaan Vo.2 Nomor.1, Desember 2017.ISSN : 2548-7990

Ghozali, Imam. (2013). Aplikasi Analisis Multivriate dengan Program SPSS. Semarang: Badan Penerbit Universitas Dipenogoro.

Hasibuan,H.M. (2014). Manajemen Sumber Daya Manusia . Jakarta :PT.Bumi Aksara.

Dahlius, A.,\& Ibrahim. (2016). Pengaruh Fasilita Kerja Terhadap Kepuasan kerja Karyawan pada PT.Bank Riau Kepri Cabang Teluk Kuantan Kabupaten Kuantan Singingi, Kuantan Singingi: Universitas Rian JOM FISIP Vol.3 No.2.

Moenir, H. (2014). Manajemen Pelayan Umum di Indonesia . Jakarta : Bumi Aksara

Nitisemito, A.S. (2010). Mamanejen Personalia manajemen Sumber Daya Manusia . Jakarta :Ghalia Indonesia.

Rifa'i, A. (2019). Pengaruh Komunikasi dan Fasilitas Kerja Terhadap Kinerja Pegawai Pada Kecamatan Sukabumi, Kabupaten Sukabumi.Juranl Ekomedia :ISSN 2252-8369;STEI PASIM,Vol.08,No.01.

Komaruddin. (2019). Manajemen Pengawasan Kualitas Terpadu.Jakarta : Rajawali Pers.

Sugiyono. (2018). Metode PenelitianManajemen. Bandung :Alfabeta. 
Sujarweni, V, Wiratna. (2019). Metode PenelitianBisnis dan Ekonomi. Yogyakarta: Pustaka Baru Press.

Sutrisno, Edi. (2017). Manajemen Sumber Daya Manusia . Jakarta :Gencana Prenada Media Gruop.

Siagian,Sondang P. (2018). Manajemen Sumber Daya Manusia . Jakarta : Bumi Aksara 